\title{
Thoughts, Words, Action: The Alma-Ata Declaration to Diabetes Care Transformation
}

\author{
Sanjay Kalra · Zhanay A. Akanov · Alex Y. Pleshkova
}

Received: April 3, 2018 / Published online: May 9, 2018

(C) The Author(s) 2018

\section{ABSTRACT}

The International Conference on Primary Health Care, held at Alma-Ata, present-day Kazakhstan, in September 1978, was a landmark in global health care. The Declaration of AlmaAta that was adopted at that conference successfully refocused attention and energy on primary health care. In a similar manner, the United Nations resolution of 2006 highlighted the dangers of the diabetes pandemic. The underlying philosophy of the Declaration of Alma-Ata is assessed in this editorial, to determine whether it remains relevant for modern and future diabetes care. We highlight the concordance between the Declaration of AlmaAta and the principles of present-day diabetes care, and come to the conclusion that the 1978

Enhanced digital features To view enhanced digital features for this article go to https://doi.org/10.6084/ m9.figshare.6216428.

S. Kalra $(\bowtie)$

Department of Endocrinology, Bharti Hospital, Karnal, India

e-mail: brideknl@gmail.com

\section{Z. A. Akanov}

Head of Center of Diabetes, Head of Clinic of Internal Diseases, Asfendyarov Kazakh National Medical University, Almaty, Kazakhstan

\section{A. Y. Pleshkova}

Clinic of Internal Diseases, Asfendyarov Kazakh

National Medical University, Almaty, Kazakhstan document is relevant for the management of the diabetes pandemic.

Keywords: Diabetes care delivery; Health economics; Health policy; Primary care; Psychosocial management; Type 1 diabetes; Type 2 diabetes

Primary health care has always been considered the Cinderella of health systems. However, it reached the high table of global health policy at the International Conference on Primary Health Care held at Alma-Ata, present-day Kazakhstan, in September 1978. This was a seminal event in health politics and led to the drafting of a sempiternal document, the Declaration of Alma-Ata [1]. Although health policy had long advocated the need for strengthening primary health care, the Alma-Ata Declaration successfully refocused attention and energy on this mode of health care delivery.

Similarly, prior to the highlighting of the dangers of the diabetes pandemic in the United Nations resolution of 2006, diabetes and other non-communicable diseases had long been neglected by public health planners and policymakers. The United Nations resolution of 2006 helped the world understand the Cassandra-like significance of the diabetes pandemic [2].

Over the past 40 years, primary health care provision has moved from thoughts and words to 
action and reality. In parallel, diabetes care has grown from its humble, ineffective beginnings into a well-developed science [3]. A relook at the philosophy underlying the Alma-Ata Declaration may help us assess the present state of diabetology and plan effectively for the future.

The Alma-Ata Declaration re-emphasizes the definition of health as a state of complete physical, mental and social well-being, and not merely as the absence of disease or infirmity. This concept is followed in diabetes care, using the frameworks of bio-psychosocial health [4]. The responsibility for action to achieve global health is placed upon multiple stakeholders, including those in the social, economic and health sectors. This too is concordant with the philosophy underlying modern diabetes care, which calls for team work and shared decisionmaking in managing the syndrome [5].

The Alma-Ata Declaration acknowledges the inequalities that exist in health care systems and notes the need to improve health as a means of achieving and improving socioeconomic development, quality of life and "world peace". This thought process is reflected in an enhanced focus on patient-reported outcomes as a target of optimal diabetes care. Current International Diabetes Federation (IDF) guidelines also recognize the inequality in health care systems and propose basic, comprehensive and standard strategies to manage diabetes [6].

The Alma-Ata Declaration reaffirms that health care is the "right and duty" of "people". This is a paraphrasing and a forerunner of the modern concept of patient-centered or personcentered care [7]. Although government bears the main responsibility of providing health care, for the management of diabetes a multisectorial effort is needed to achieve optimal socio-economic productivity. It is clear that the diabetes pandemic cannot be managed without the involvement of all concerned stakeholders, including the individual and the community.

In this context, the Alma-Ata Declaration predates twenty-first century diabetes care by four decades. It defines primary health care as "essential" health care which is built on practical, scientifically sound, socially acceptable methodology. This is syncretic with the concept of diabetes being a family and societal condition, as well as the widespread use of technology to improve diabetes prevention and care [8].

Primary care is important as it is the first point of contact between individuals and the health care system. While it is accepted as the "first element", it is also part of a "continuing health care process". Thus, the Alma-Ata concept of primary care is absorbed into the chronic care model that characterizes diabetes [9].

The Alma-Ata Declaration provides an overarching definition and description of the components of primary health care. Promotive, preventive, curative and rehabilitative services are included in the ambit of primary care. Although the document does not specify any chronic disease, it explicitly states that "prevailing health problems" should be addressed by education, prevention and control. Modern diabetology relies on therapeutic patient education and self-management education to ensure healthy living with diabetes [10]. Thus, the approach used represents a conversion of the words penned at Alma-Ata into action.

In 1978, a call was made to formulate national policies, strategies and plans of action to utilize primary health care. This policy has borne fruit in most countries across the world. The call for "Early Action", made as part of the Berlin Declaration, reiterates the need for proactive national policies on diabetes [11]. The multinational character of recent initiatives in diabetes prevention and management reiterate the request in the Alma-Ata Declaration to all countries to "cooperate in a spirit of partnership and service".

The issue of international cooperation in the organization of primary health care is an important component of health systems of all countries. All citizens are special recipients of socially oriented medical care, and any practical innovation in this area helps raise the quality of care to a higher level. In general, the patient-centered care model is another name for the principles and philosophy of the Alma-Ata Declaration. The application of these principles in diabetes care indicates the humanity of the global health system. This is especially important in the context of the growing diabetes pandemic.

The 1978 Alma-Ata Conference hoped for "Health for All" by 2000. Sadly, however, 
billions of our fellow human beings still do not have access to optimal health care. Similarly, millions of men and women with diabetes continue to be undiagnosed or untreated, or their disease remains uncontrolled [12]. This is reason enough for us to remember the Alma-Ata Conference and the document which emerged from it and re-dedicate ourselves to its philosophy and ideals.

In his work "The Book of Words" the famous Kazakh philosopher Abay Kunanbayev encourages literacy and education as a means of progress [13]. This is true in diabetes care as well, where both health care providers and persons living with diabetes must upgrade their knowledge and skills in order to manage diabetes in an optimal manner. They also have to work in collaboration with other medical and nonmedical stakeholders, all of whom form a complex "diab-ecosystem" which influences diabetes outcomes.

Strengthening this diab-ecosystem at the primary level is the most efficient strategy to limit the impact of diabetes. Thus, the Alma-Ata Declaration assumes even greater relevance as we tackle the diabetes epidemic of the twentyfirst century.

\section{ACKNOWLEDGEMENTS}

Funding. No funding or sponsorship was received for this study or publication of this article.

Authorship. All named authors meet the International Committee of Medical Journal Editors (ICMJE) criteria for authorship for this article, take responsibility for the integrity of the work as a whole, and have given their approval for this version to be published.

Disclosures. Sanjay Kalra, Zhanay Akanov and Alex Y. Pleshkova have nothing to disclose.

Compliance with Ethics Guidelines. This article does not contain any studies with human participants or animals performed by any of the authors.
Open Access. This article is distributed under the terms of the Creative Commons Attribution-NonCommercial 4.0 International License (http://creativecommons.org/licenses/ by-nc/4.0/), which permits any noncommercial use, distribution, and reproduction in any medium, provided you give appropriate credit to the original author(s) and the source, provide a link to the Creative Commons license, and indicate if changes were made.

\section{REFERENCES}

1. World Health Organization. Alma Ata declaration. Geneva: World Health Organization; 1978.

2. Silink M. United Nations resolution on diabetes. Pract Diabetes. 2006;23(7):279.

3. Cornell S. Continual evolution of type 2 diabetes: an update on pathophysiology and emerging treatment options. Ther Clin Risk Manag. $2015 ; 11: 621-32$.

4. Kalra S, Baruah MP, Sahay R. Salutogenesis in type 2 diabetes care: a biopsychosocial perspective. Indian J Endocrinol Metab. 2018;22(1):169-72.

5. Kalra S, Unnikrishnan AG, Baruah MP. Interaction, information, involvement (The 3I strategy): rebuilding trust in the medical profession. Indian J Endocrinol Metab. 2017;21(2):268-70.

6. International Diabetes Federation. Clinical Guidelines Task Force. Global guideline recommendations for type 2 diabetes: for standard, comprehensive, and minimal care. Diabet Med. 2006;23(6):579-93.

7. Kalra S, Megallaa MH, Jawad F. Perspectives on patient-centered care in diabetology. J Mid Life Health. 2012;3(2):93-6.

8. Kalra S, Balachandran K. Technosocial competence in diabetology. Indian $\mathrm{J}$ Endocrinol Metab. 2017;21(4):489-91.

9. Kalra S, Baruah MP, Kalra B. Diabetes care: evolution of philosophy. Indian $\mathrm{J}$ Endocrinol Metab. 2017;21(4):495-7.

10. Assal JP, Mühlhauser I, Pernet A, Gfeller R, Jörgens $\mathrm{V}$, Berger M. Patient education as the basis for diabetes care in clinical practice and research. Diabetologia. 1985;28(8):602-13. 
11. Kalra S, Lauritzen T, Sharmanov T, Akanov Z, Al Awadi F, Das AK, et al. Alma-Ata to Berlin: diabetes prevention and treatment to achieve healthy living. Diabet Med. 2017;34(8):1169-70.

12. Ogurtsova K, da Rocha Fernandes JD, Huang Y, Linnenkamp U, Guariguata L, Cho NH, et al. IDF diabetes atlas: global estimates for the prevalence of diabetes for 2015 and 2040. Diabetes Res Clin Pract. 2017;1(128):40-50.

13. Kunanbayev A. The book of words. http://www. leneshmidt-translations.com/book_of_words_abai_ kunanbaev_english/index.htm. Accessed 6 Mar 2018. 